Published in final edited form as:

Infect Dis Clin North Am. 2009 September ; 23(3): 643-664. doi:10.1016/j.idc.2009.04.013.

\title{
Acute Infective Endocarditis
}

\author{
Jay R. McDonald, MDa,b \\ a Staff physician, Infectious disease section, St. Louis VA Medical Center, St. Louis, MO \\ ${ }^{b}$ Assistant Professor of Medicine, Division of Infectious Diseases, Washington University School of \\ Medicine, St. Louis, MO
}

\section{Keywords}

Endocarditis

\section{Introduction}

Despite advances in medical and surgical therapy, infective endocarditis (IE) remains a highly morbid and deadly infection. Endocarditis is an inflammation of the endocardium, the inner lining of the heart and heart valves. While such inflammation can be caused by a variety of disease states, the majority of endocarditis is caused by infectious agents.

In his Gulstonian lectures of 1885, Sir William Osler drew a distinction between "simple" and "malignant" forms of endocarditis [1]. The "simple" form described by Osler correlates to what has become known as subacute bacterial endocarditis. Subacute IE typically presents with subtle constitutional symptoms, and is frequently not diagnosed until it has been present for months. The "malignant" form described by Osler, characterized by an acute onset and fulminant course, correlates to what is now known as acute IE. The focus of this review will be acute IE, though many studies of diagnosis and treatment do not differentiate between acute and subacute disease, and indeed many of principles of diagnosis and management of IE are identical between acute and subacute disease.

\section{Pathogenesis}

Vegetation formation is a multistep process. The first step is endocardial injury, which may occur by many mechanisms. The most common mechanism is injury by turbulent blood flow from an acquired or congenital intracardiac abnormality. The most common site of such injury, and thus the most common site of vegetation formation, is on the line of closure of a valve surface, typically on the atrial surface of atrioventricular valves, or the ventricular surface of semilunar valves [2]. Alternatively, an intravascular catheter or other device may directly abrade the endocardium. In injection drug users, direct injection of contaminating debris may damage the tricuspid valve surface.

Corresponding author for proof and reprints: Jay R. McDonald, MD, St. Louis VA Medical Center, 915 N Grand Blvd, Mailcode 151/ JC, St. Louis, MO 63106, (314) 289-7064, (314) 289-7604 (fax), Email: Jay.McDonald1 @ va.gov.

Conflict of Interest Statement: The author has no conflicts of interest to disclose.

Publisher's Disclaimer: This is a PDF file of an unedited manuscript that has been accepted for publication. As a service to our customers we are providing this early version of the manuscript. The manuscript will undergo copyediting, typesetting, and review of the resulting proof before it is published in its final citable form. Please note that during the production process errors may be discovered which could affect the content, and all legal disclaimers that apply to the journal pertain. 
The endothelial damage triggers sterile thrombus formation, which occurs by deposition of fibrin and platelets. Though mechanical endocardial damage usually precedes sterile thrombus formation, a sterile thrombus can be induced without direct trauma [3]. Physiologic stresses such as hypersensitivity states, hormonal changes, and high altitude can also induce sterile endocardial thrombosis [3]. Clinical states associated with sterile thrombus formation in humans include malignancy, rheumatic diseases, and uremia.

Once a sterile thrombus is present, transient bacteremia can seed the thrombus. Bacteria are introduced into the bloodstream when a body surface that is heavily colonized by bacteria (oral cavity, gut lumen, genitourinary mucosa) is traumatized. Routine daily activities such as chewing food and tooth brushing lead to frequent low-level, transient bacteremias in healthy adults [4]. Bloodborne bacteria may adhere to the damaged endocardial surface. Bacteria have different adhesive capacity, based on bacterial surface characteristics and virulence factors called adhesins. For example, the adhesive properties of viridans streptococci are related the amount of dextran present in the streptococcal cell wall, as well as specific surface proteins such as FimA [5,6].

Once bacteria have attached to the endocardium, the vegetation "matures" through additional deposition of fibrin and bacterial proliferation. Histologically, the vegetation consists primarily of fibrin, platelets, and bacteria; the absence of vasculature makes penetration by phagocytic cells rare. The majority of bacteria in a mature vegetation are found below the surface of the vegetation, protected from phagocytes and high concentrations of antibiotics.

\section{Epidemiology}

\section{Demographics and Risk Factors}

The incidence of IE is between 2 and 10 episodes per 100,000 person-years in most populationbased studies [7-9], and as high as 20 episodes per 100,000 person-years in the elderly [10]. There are approximately 15,000 new cases of IE diagnosed each year in the United States, and it accounts for about 1 in 1000 admissions to the hospital [11].

Most studies demonstrate that the rate of IE has been stable over time [12,13], though changes in diagnostic tools and criteria make temporal comparisons difficult. Despite a relatively stable rate, the nature of IE has changed dramatically over the past several decades. IE is more commonly associated with invasive medical procedures and old age, and less associated with rheumatic heart disease and poor dentition [14,15]. These epidemiologic trends support the observation that acute IE is increasing in frequency relative to subacute and chronic IE: in the preantibiotic era, approximately $20 \%$ of IE was acute, while more recent studies show that about $33 \%$ of IE is acute $[12,16]$.

IE is more common in men than women [11], and is more common with increasing age [10]. The mean age of IE patients has increased over time, from under 30 years in the pre-antibiotic era [17] to nearly 60 years in 1990s [18]. In the elderly, IE is more often associated with intracardiac prosthetic devices and bacteria from the gastrointestinal tract [19]. In a large observational cohort study, IE most commonly involved the mitral valve only (approximately $40 \%$ of patients), followed by the aortic valve only ( $36 \%$ of patients), followed by multivalvular disease $[18,20]$. Right-sided valves are rarely affected except among injection drug users. The pulmonic valve is least likely to be involved in IE.

Structural heart disease is a risk factor for IE because it results in turbulent blood flow. About $75 \%$ of patients who develop IE have underlying structural heart disease [13]. In the past, rheumatic heart disease with mitral stenosis was the most common valvular defect in patients with IE. Recently, the most common predisposing lesions are mitral regurgitation, aortic valve 
disease (stenosis and regurgitation), and congenital heart disease [21,22]. Mitral valve prolapse is a risk factor for IE, primarily when regurgitation is present [23].

The presence of a prosthetic cardiac valve is a strong risk factor for IE. The risk is highest in the first year after valve implantation. Mechanical valves are associated with higher risk than bioprosthetic valves in the first years after surgery, but that relationship reverses in later years after surgery [2]. Implanted valve rings are associated with lower risk of IE than prosthetic valves [24].

In addition to structural heart disease and prosthetic valves, established risk factors for IE include prior episodes of IE, invasive medical procedures, and injection drug use. Some studies have demonstrated that diabetes mellitus and kidney disease may be risk factors as well [25].

Nosocomial IE is increasing in frequency and importance. Between $14 \%$ and $31 \%$ of all IE is nosocomial in recent case series [26-28]. In a longitudinal single-center study in Spain, the proportion of IE that was acquired in the hospital increased almost ten-fold in a 15-year period. Compared to community-acquired IE, nosocomial IE was associated with three-fold higher mortality, and was most commonly caused by $S$. aureus, coagulase-negative staphylococci, and enterococci [27].

\section{IE in Critical Care}

Because IE often occurs in patients with multiple co-morbid illnesses and those who have undergone recent invasive procedures, it is commonly diagnosed and treated in the intensive care unit (ICU).

From 1993-2000, IE was diagnosed in 3\% of ICU patients in 2 medical ICUs in France [29]. Among 228 cases of IE in this study, 64\% of cases were native valve endocarditis (NVE), of which $21 \%$ were nosocomial. S. aureus was the causative agent in half of all IE cases.

Complications were frequent: Neurological events complicated $40 \%$ of cases, CHF 29\%, and septic shock $26 \%$. In-hospital mortality was $45 \%$. Septic shock, neurological complications, and immunocomprimise predicted in-hospital mortality [29].

In another study taking place between 1994 and 1999, IE was identified in $0.8 \%$ of all ICU patients in 4 medical ICUs in Vienna, Austria [30]. Just over half of the 33 patients came to the ICU with the diagnosis of IE, while $45 \%$ of them were first diagnosed in the ICU. The majority (79\%) had NVE, and S. aureus was the most common pathogen, causing $36 \%$ of IE. Severity of illness was high, with $79 \%$ of patients receiving mechanical ventilation, $73 \%$ receiving vasopressors, and 54\% dying during their hospital stay. Acute renal failure occurred in $39 \%$ of patients, and was the only independent predictor of mortality [30].

Nosocomial IE in the ICU can usually be attributed to a hospital acquired infection at another primary site. Of 31 nosocomial cases of IE described by Mourvillier et al, 21 were related to intravenous catheter infection and 3 to surgical site infection [29]. In another study, among 22 nosocomial IE cases in an ICU, 11 were related to an intravascular device and 8 to a surgical site infection. Fifteen of these 22 patients had no predisposing cardiac lesion. S. aureus was the causative pathogen in $68 \%$ of patients, and $68 \%$ of the patients died [31].

Wolff et al described 122 cases of prosthetic valve endocarditis (PVE) in a French ICU from 1978 to 1992 [32]. S. aureus accounted for $61 \%$ of disease occurring in the first 2 months after valve implantation, and streptococci and $S$. aureus were the most common causes of late disease. Heart failure was seen in half of cases, and mortality was $34 \%$ at 4 months. Predictors of mortality among S. aureus cases were septic shock, heart failure, mediastinitis, and elevated prothrombin time [32]. 


\section{Approach to the Patient}

\section{Diagnosis}

Diagnostic Criteria-The Duke Criteria incorporate information from echocardiography, history and physical exam, microbiology, and pathology to diagnose IE (Table 1). They were originally proposed in 1994 [33], and were subsequently shown to be superior to previous diagnostic criteria [34,35]. The criteria were modified in 2000 to revise the definition of "possible IE," add criteria for microbiologic diagnosis of Q fever IE, eliminate echocardiographic minor criteria, and include recommendations for choosing between transthoracic echocardiography (TTE) and transesophageal echocardiography (TEE) [36].

History and Physical Exam - The clinical presentation of subacute IE is variable, but the presentation of acute IE is more straightforward. Unlike patients with subacute IE who typically report longstanding constitutional symptoms, patients with acute IE typically describe the abrupt onset of fever and rigors, and may present with symptoms of embolism. The history should include specific inquiry about known risk factors for IE, including invasive procedures, injection drug use, structural heart disease, and prior endocarditis. Symptoms referable to other organ systems may indicate a primary source of bacteremia. Complications of IE may be apparent from the history, including heart failure, conduction disturbances, or embolism.

The physical exam must be comprehensive, with special attention to examination of the heart, dentition, all sites of invasive devices and recent procedures, and potential destinations of embolism. Heart murmur is present in $85 \%$ of patients with IE, but a changing murmur is only apparent in 5 to $10 \%$ of cases. About half of patients with IE have evidence of embolic phenomena on physical exam [2,11]. When clinical suspicion is present, a lack of clinical findings does not rule out the diagnosis of IE.

Laboratory tests-At least three blood cultures should be drawn when IE is suspected, with the first and last drawn at least one hour apart. The microbiology lab should be informed that IE is on the differential diagnosis, if fastidious organisms are suspected. Electrocardiogram, chest radiograph, urinalysis, and rheumatoid factor may assist in making the diagnosis or identifying complications of IE.

Echocardiography-Diagnosis of IE is made in part by echocardiographic findings. The presence of an oscillating intracardiac mass, either on a valve, in the path of a regurgitant jet, or on implanted material, is the classic finding, though abscess or new partial dehiscence of a prosthetic valve also meets diagnostic criteria [36]. Other findings associated with IE include aneurysm, fistula, and leaflet perforation [37].

The use of echocardiography to rule out IE should be based on the clinician's pretest probability of disease. Pretest probability, in turn, is based on the presence of clinical and microbiologic features unique to each patient, including the likelihood of alternative diagnoses. Studies have proposed algorithms for use of echocardiography to diagnose IE $[38,39]$. While these studies can not substitute for the judgment of an experienced clinician, they highlight some of the features which impact on pretest probability of IE: presence of bacteremia, type of organism, presence of known IE risk factors, and clinical exam.

TTE and TEE both have a role in the diagnosis and evaluation of IE. TTE has low sensitivity compared to TEE (46\% vs. 93\%), though both are highly specific (95\% vs. 96\%) [2]. TTE is a reasonable first test in patients with low pretest probability of IE despite its sensitivity of less than 50\% [40]. In some patients who undergo TTE and are found to have IE, subsequent TEE may be advisable to evaluate perivalvular extension of disease, vegetation size, and other factors which may inform surgical decision-making. In patients with higher pretest probability 
for disease, or in whom TTE is rendered less sensitive by obesity, lung hyperinflation, or valve prosthesis, TEE is the initial echocardiographic modality of choice in IE [40]. Several studies have demonstrated that TTE alone will miss a significant number of cases of IE in patients with medium to high pretest probability of disease, including those meeting Duke criteria for "possible" IE, and patients with $S$. aureus bacteremia [41,42].

Alternative imaging modalities-Cardiac CT and MRI have been reported to diagnose complications of IE, including aortic root abscesses and arteriovenous fistulae [37]. Current limitations to these modalities include difficulties in evaluating valve motion, spatial resolution, and time required to acquire images [37]. A recent study of cardiac multislice CT showed that its test characteristics were similar to TEE for the diagnosis of IE in 37 patients, 29 of whom underwent cardiac surgery, though all 4 leaflet perforations were missed with CT [43]. While CT and MRI may be useful as an adjunct to echocardiography in selected cases at centers with expertise in these techniques, they are not part of the current standard of care in the routine diagnosis of IE. The technology involved in cardiac CT and MRI is evolving rapidly, and at some point in the future they may be useful in IE diagnosis.

\section{Antibiotic Therapy: General Principles}

All patients with IE should receive antibiotic therapy, and more than half of cases are managed with antibiotic therapy alone [40]. Some organism-specific recommendations for treatment are discussed below in the "Specific organisms" section. A recent scientific statement by the American Heart Association provides an excellent summary of evidence and antibiotic recommendations, and should be consulted for IE cases that are beyond the scope of this review [40].

Though treatment must be individualized, some general principles of antibiotic therapy apply to all patients. Because the vegetation structure sequesters bacteria from the bloodstream, long durations of therapy are necessary. Parenteral antibiotics are preferred over oral regimens because of the need for sustained and reliable blood levels of antibiotic. Blood cultures should be drawn every 24 to 48 hours after initiation of antibiotics, until they are negative. Duration of treatment should be counted from the time of the first negative blood cultures. If vancomycin or an aminoglycoside is used, drug levels should be monitored to ensure adequate dosing and to prevent toxicity $[11,40]$.

Aminoglycosides are often used in combination with a cell wall-active agent ( $\beta$-lactam or vancomycin) for synergy in the treatment of IE caused by staphylococci, streptococci, and enterococci. Cell wall-active agents increase aminoglycoside entry into bacteria, and therefore synergy requires dosing in close temporal proximity to one another. The use of combination therapy is supported by in vitro and animal studies, but clinical data in humans are scarce [44]. A recent meta-analysis of clinical trials of combination therapy included 261 patients with IE due to $S$. aureus or viridans streptococci in 5 separate studies. There was no benefit of combination therapy in terms of mortality or treatment success [45]. However, in a single study, combination therapy for $S$. aureus IE did reduce the duration of bacteremia, though it did not improve clinical outcomes [46]. Because of the small size of these studies, it is possible that a meaningful clinical benefit does exist, but studies have not been adequately powered to detect it.

\section{Surgical Therapy}

Decisions regarding surgical therapy for patients with IE are multifactorial and complex, and the need for surgery should be individualized to each patient. For these reasons, early input from an experienced cardiothoracic surgeon can be invaluable in managing a patient with IE. Among all patients with IE, 40-45\% eventually undergo surgery, and rates of surgery are 
similar for NVE and PVE. Predictors of surgery include younger age, CHF, abscess, and coagulase-negative staphylococcal IE [47,48]. The majority of surgery for IE is performed for hemodynamic indications such as congestive heart failure [49].

Because there have been no randomized controlled trials of surgical plus medical therapy versus medical therapy alone in the treatment of IE, current guidelines for surgical treatment of IE are based primarily on observational data, which are prone to biases such as confounding by indication, and survival treatment selection bias [50]. Because of these biases, careful adjustment for factors associated with risk of death and likelihood of receiving surgery are necessary.

Several recent studies have attempted to account for these factors, and results have been conflicting regarding the benefit of surgery. In a study reporting a ten-year experience at seven US hospitals, 230 of 513 adults with NVE underwent cardiac surgery. After propensity analyses to account for differences in treatment assignment and prognostic factors, surgery was associated with reduced mortality ( $15 \%$ vs. $28 \%, \mathrm{p}=.01)$, especially in patients with moderate to severe heart failure (14\% vs. $51 \%, \mathrm{p}=.001)$ [51]. In contrast, a study that matched 27 surgical and 27 non-surgical ICU patients with IE by propensity score found no benefit of surgery (OR 0.96) [29]. A study of NVE from the International Collaboration on Endocarditis Merged Database, which included patients from 7 centers in 5 countries, showed a survival benefit from surgery only in patients in the highest quintile of surgical likelihood (11.2\% in the surgery group vs. $38.0 \%$ in the no surgery group, p<.001) [52]. A study of PVE from the same study group found a statistically non-significant benefit of surgery $(22.1 \%$ in the surgery group vs. $32.4 \%$ in the no surgery group, $\mathrm{p}=0.18$ ) in patients with PVE matched on propensity score [48]. Finally, in an analysis of an 18-year experience with left-sided IE at a single center in the USA, after matching by propensity score, decade of diagnosis, and follow-up time, surgery was not significantly associated with mortality (adjusted HR 1.3, 95\% confidence interval $0.5-$ 3.1) [53]. Thus, the benefit of surgery is unclear, and is likely restricted to specific subgroups of patients.

There are several subgroups of patients in which early surgery should be strongly considered. Patients with CHF or severe valvular dysfunction likely to precipitate acute CHF should be considered for surgery, particularly when the aortic valve is involved [51,54-57]. Patients with intracardiac abscess should be strongly considered for surgery, in light of decreased penetration of antibiotics to the site of infection [58], and the possibility of the abscess causing heart block acute valvular dysfunction $[54,57,58]$. Patients with IE caused by organisms known to be refractory to medical management, including Pseudomonas, Candida, and multi-drug resistant organisms, may benefit from surgical management, as well as those at highest risk for embolism $[40,54,55]$.

Patients with PVE should be carefully considered for surgery $[47,48,55]$, though low-risk patients with PVE may be adequately managed with medical therapy alone $[59,60]$. Characteristics which suggest lower risk include absence of heart failure, abscess, or valve dehiscence, and those whose IE is caused by less virulent organisms such as viridans streptococci [59].

\section{Right-sided IE}

Right-sided IE, which accounts for about $10 \%$ of cases of IE, occurs most commonly in injection drug users, and has different clinical characteristics and outcomes compared to leftsided IE $[61,62]$. Patients with right-sided IE are typically younger, with fewer comorbid medical conditions and less underlying valve disease than patients with left-sided IE $[61,63]$. S. aureus is responsible for about $70 \%$ of right-sided IE $[61,62,64]$. Patients with right-sided IE often present with signs and symptoms of septic pulmonary emboli, including pleuritic chest 
pain, dyspnea and hemoptysis. More than half present with chest radiograph consistent with septic pulmonary emboli [65]. The mortality rate among patients with right-sided IE is typically less than $10 \%$ [61-63].

In a study of 1529 episodes of IE in injection drug users in Spain, 79\% had right-sided IE, 16\% had left-sided IE, and 5\% had both [61]. Only $1 \%$ of the right-sided IE was of the pulmonic valve. It has not been definitively established why the tricuspid valve is so frequently involved in IE in injection drug users. While it may be related to valve damage caused by bombardment of the tricuspid valve by impurities in injected material, this damage has not always been apparent in autopsy studies of injection drug users. Other theories include drug-induced microthrombi on the valve, drug-induced pulmonary hypertension, and increased right-sided expression of molecules which bind bacteria [61,64].

Carefully selected cases of tricuspid valve IE may be managed with short courses of parenteral antibiotics, or with oral regimens [40,61,62,66,67]. Patients with factors associated with poor prognosis, including concurrent left-sided IE, metastatic infection, heart failure, large vegetation, or immune compromise should not be considered for shorter course therapy or oral regimens [40].

\section{Prosthetic Valve Endocarditis (PVE)}

The risk of PVE is 1 to $5 \%$ in the first year after implantation, and decreases to about $1 \%$ per year thereafter $[68,69]$. The risk of PVE is similar overall among mechanical and bioprosthetic valves, though early IE risk may be higher and late IE risk lower among mechanical valves compared to bioprosthetic valves [69-71]. PVE risk is comparable among valves in the aortic and mitral positions [69-71]. PVE occurring in the first 12 months after surgery is most often caused by coagulase-negative staphylococci or S. aureus [70], while late-onset PVE has similar microbiology to NVE [71,72]. Mortality in PVE is predicted by heart failure, S. aureus, and the presence of intracardiac abscess or fistula [32,73-75].

Surgical therapy for PVE is frequently indicated, as discussed above, and is performed in about half of all cases of PVE [75]. Recommendations for medical therapy in the treatment of PVE are generally similar to those for treatment of NVE, though they differ substantially for staphylococcal PVE. For PVE caused by oxacillin-susceptible strains of staphylococci, duration of nafcillin or oxacillin should be at least 6 weeks, rifampin should be added for the same duration, and low-dose gentamicin should be given for 2 weeks [40].

\section{Cardiovascular Device-Related IE}

Use of intracardiac pacemakers and implantable cardioverter-defibrillators (ICDs) has been steadily increasing, but infection of these devices has been increasing even more rapidly [76]. Most infections of pacemakers and ICDs occur only at the pocket, but $10 \%$ of pacemakerassociated infections include IE [77]. Pacemaker/ICD IE is best diagnosed with TEE, as TTE has sensitivity of less than $30 \%$ for lead vegetations [78,79]. However, it may be impossible to definitively distinguish a sterile thrombus from an infected thrombus on a lead [2]. An intracardiac oscillating mass on a pacemaker/ICD lead qualifies as a major criterion in the Duke criteria for IE diagnosis [36].

There have been no randomized studies of device removal plus antibiotics versus antibiotics alone in the treatment of pacemaker/ICD IE, but optimal management includes removal of the device, at a minimum until bacteremia clears, but longer if possible. One retrospective study of any pacemeaker/ICD infection showed a relapse rate of less than $1 \%$ among 117 patients who underwent device removal, and 50\% among 6 patients in whom the device was retained 
[79]. If a pacemaker/ICD must be replaced before completion of therapy, it may be advisable to treat as PVE.

\section{Specific organisms}

For IE caused by organisms not addressed below or in Tables 2 and 3, the American Heart Association's Scientific Statement on Infective Endocarditis should be consulted for treatment recommendations [40].

\section{Staphylococcus aureus}

$S$. aureus is the leading cause of acute IE. The incidence of $S$. aureus IE has been steadily increasing in recent decades, becoming the predominant organism in IE in most reports [40, 80,81]. Increasing use of intravenous catheters and implanted prosthetic devices have led to higher rates of healthcare-associated staphylococcal bacteremia, placing more patients at risk for IE [81].

S. aureus IE tends to involve the mitral valve more often than the aortic, and is the most common cause of IE among injection drug users [18]. IE caused by community-associated strains of methicillin-resistant $S$. aureus (CA-MRSA), compared to strains of hospital-acquired MRSA, occurs in a younger population with a higher prevalence of injection drug use [82]. S. aureus IE is associated with higher rates of embolism and mortality compared to IE caused by other organisms $[18,83,84]$. In a large cohort study of S. aureus IE, embolism occurred in $60 \%$ of cases of $S$. aureus IE versus $31 \%$ of cases caused by other organisms. [18].

NVE caused by methicillin-susceptible strains of S. aureus (MSSA) should be treated with 6 weeks of intravenous (IV) nafcillin or oxacillin (Table 2). Gentamicin can be added for 3 to 5 days at $3 \mathrm{mg} / \mathrm{kg} / \mathrm{day}$ in 2 or 3 divided doses, though its use is considered optional based on existing studies and potential toxicities $[45,85,86]$. MRSA IE should be treated with vancomycin alone for 6 weeks, with goal vancomycin troughs of 10-15 micrograms/dl [40]. Antibiotic therapy for PVE caused by S. aureus is shown in Table 3.

\section{Coagulase-negative staphylococci}

While coagulase-negative staphylococci cause about $6 \%$ of NVE, they cause very little acute IE [87]. Coagulase-negative staphylococcal IE caused is more indolent than IE caused by other organisms. One significant exception is the species $S$. lugdunensis, a coagulase-negative staphylococcus that behaves clinically like $S$. aureus, and has been described to cause acute IE with an aggressive clinical course [88]. In the first year after prosthetic valve implantation, coagulase-negative staphylococci are the second most common cause of PVE, after $S$. aureus [72]. IE caused by coagulase-negative staphylococci should be treated with antibiotic regimens similar to those used to treat $S$. aureus (Tables 2 and 3).

\section{Streptococci}

Streptococcal IE comprises about $30 \%$ of all IE, though it is less prevalent among acute IE [18]. Most streptococcal IE is caused by viridans streptococci, which are oral flora and include S. mitis, S. mutans, S. salivarius, S. sanguis, and the $S$. intermedius group (S. intermedius, $S$. anginosus, and $S$. constellatus) [11].

S. bovis, a group D streptococcal species, is the most common non-viridans streptococcal species to cause IE [89]. S. bovis bacteremia is strongly associated with colon polyps and cancer [90]. S. bovis accounts for 5 to 15\% of cases of IE in the United States [89]. Other streptococci account for less than 5\% of cases of definite IE [18]. Treatment of IE caused by viridans streptococci or by S. bovis depends on the degree of penicillin resistance of the infecting 
organism. Aminoglycosides are recommended in some settings for synergistic effects, though clinical data in humans is incomplete [40,45,86]. See Tables 2 and 3 for treatment recommendations.

\section{Enterococci}

After staphylococci and streptococci, enterococci are the third leading cause of IE, causing about $10 \%$ of cases [20,81]. Enterococcal IE tends to occur in older men with many comorbid medical conditions [20,91]. It occurs disproportionally on the aortic valve, and is less commonly associated with embolic events compared to IE caused by other organisms [20].

Enterococci were formerly designated as a member of genus streptococcus, but now are a genus unto themselves. Unlike streptococci, enterococci are relatively resistant to penicillin, ampicillin, and vancomycin, and killing of susceptible strains often requires the addition of gentamicin or streptomycin for synergy. For this reason, all enterococcal isolates in IE cases should be tested for high-level resistance to gentamicin and streptomycin. Current guidelines suggest 4 to 6 weeks of aminoglycoside in combination with a cell-wall active agent for IE caused by appropriately susceptible isolates [40], but observational data suggest that outcomes may be similar when the aminoglycoside is given for a shorter duration [92]. In cases where aminoglycoside is contraindicated because of toxicities, or when high-level resistance is present, there is in vitro data [93] but limited clinical data [94] suggesting that the combination of ampicillin and ceftriaxone achieve synergistic killing of susceptible enterococci, and may be a reasonable therapeutic alternative when aminoglycosides can not be used. See Tables 2 and 3 for treatment recommendations.

\section{Gram Negative Bacilli}

Gram negative bacilli account for approximately $5 \%$ of IE diagnoses. These can be divided into HACEK and non-HACEK IE. The acronym HACEK stands for Haemophilus, Actinobacillus, Cardiobacterium, Eikenella, and Kingella. IE due to HACEK organisms is rarely acute [11]. Older literature suggest that these fastidious organisms require prolonged incubation periods to grow in the microbiology lab, but with modern culture techniques, most HACEK organisms grow within 5 days [95].

In a recent international cohort including 2761 cases of IE from 2000 to 2005, only $1.8 \%$ of cases were caused by non-HACEK gram-negative organisms, most commonly Escherichia coli and Pseudomonas aeruginosa [96]. Unlike older case series in which injection drug use was strongly implicated in the majority of cases [97,98], most cases in this cohort $(57 \%)$ were healthcare-acquired, and mortality was high (24\%) [96].

\section{Complications}

\section{Congestive Heart Failure}

CHF is the most common complication of both NVE and PVE, occurring in over half of all cases of IE [2]. It is usually caused by valvular dysfunction, not myocardial failure [54], and is most commonly associated with aortic valve dysfunction [56,57]. In retrospective studies of IE patients with CHF, medical management alone is associated with higher mortality than surgical and medical management combined [56], even after adjustment for propensity to receive surgical therapy [51].

\section{Intracardiac Abscess}

Intracardiac abscesses occur in approximately 10 to $40 \%$ of cases of IE $[58,99,100]$, and are particularly common in PVE and aortic valve disease [56,58]. Abscess related to the aortic valve can extend into the conduction system, causing heart block [54,56,58]. S. aureus is the 
organism most commonly associated with intracardiac abscess $[58,99,100]$. Diagnosis usually requires TEE, though even TEE has a sensitivity of only about 50\% compared to intraoperative examination [101]. Surgical intervention is usually necessary to achieve cure of abscess [54, 99].

\section{Embolism}

Embolic events occur in 20 to $50 \%$ of patients with IE $[102,103]$. The central nervous system is the most common destination of embolism, followed by the spleen, kidneys, lungs, and liver $[55,102]$. Risk of embolism is highest in the time immediately following after diagnosis, and risk decreases once antibiotic therapy has been initiated [104,105]. Vegetations measuring greater than 10 millimeters, and vegetations on the anterior mitral valve leaflet are most likely to embolize [55].

Central nervous system embolism accounts for 40 to $65 \%$ of all embolic events in IE, and the middle cerebral artery is the most common site [102,104]. In a study of 60 patients with leftsided IE who underwent brain MRI, cerebrospinal fluid analyses, and structured neurological exams, 35\% of patients had a symptomatic cerebrovascular event, and another $30 \%$ had an asymptomatic event, for a total incidence of $65 \%$ [106]. The risk of CNS embolism declines after initiation of antimicrobial therapy [106,107]. In a prospective study of 1437 patients with left-sided IE at 61 medical centers, the risk of CNS embolism declined by $65 \%$ between the first and second week of antibiotics [108].

\section{Mortality}

Mortality among IE patients has been estimated at 15 to $20 \%$ during the index hospitalization, and 20 to $30 \%$ at one year [20,103,108-110]. Mortality is similar between NVE and PVE, and between mitral and aortic IE [55]. Right-sided IE has lower mortality than left-sided disease [55]. In NVE, viridans streptococci and enterococci are associated with lower mortality compared to $S$. aureus [20]. IE caused by gram-negative bacilli and fungi has greater than $50 \%$ mortality [55]. Nosocomial acquisition of IE [111], older age [103], immunocompromise [29], diabetes mellitus [108], APACHE II score [108], hemodynamic instability [29], altered mental status $[29,110,111]$ and renal failure $[103,110,111]$ are significant predictors of mortality. IE complications which are predictive of mortality include CHF [18,103], intracardiac abscess [18], embolism [29,110,111], and large mobile vegetation [27,103,110].

\section{Prevention}

Though there have been no randomized controlled trials that prove the effectiveness of IE prophylaxis around the time of dental, GI, or GU procedures, it has been common practice since the 1950's [112]. Recent literature, however, has shown that only a small percentage of IE cases are attributable to dental procedures, and that a huge amount of prophylaxis would be needed to prevent only a small number of cases [112-114].

The most recent practice guideline from the American Heart Association for the Prevention of Infective Endocarditis, published in 2007, calls into question many of the long-held assumptions about IE prevention, and contains many new and revised recommendations [112]. Prophylaxis solely for IE prevention is recommended only in patients undergoing a highrisk procedure, and with a high-risk cardiac lesion. A high-risk procedure is defined as: 1) any dental procedure that involves manipulation of gum tissue, or the periapical region of teeth, or perforation of oral mucosa; 2) invasive respiratory tract procedure involving breaks in the respiratory mucosa; or 3) invasive procedure involving infected skin or soft tissue. A high-risk cardiac lesion is defined as one of the following: 1) prosthetic heart valve or prosthetic material used in a valve repair; 2) previous IE; 3) unrepaired cyanotic heart disease; 4) completely 
repaired congenital heart defect in the first 6 months after repair only; 5) repaired congenital heart defect with residual defect adjacent to prosthetic material; or 6) cardiac transplant recipient with cardiac valvulopathy. Prophylaxis is no longer recommended for those undergoing GI or GU procedures [112].

\section{Summary}

Acute IE is a complex disease with changing epidemiology and a rapidly-evolving knowledge base. In order to consistently achieve optimal outcomes in the management of IE, the clinical team must have an understanding of the epidemiology, microbiology, and natural history of IE, as well as guiding principles of diagnosis and medical and surgical management.

\section{Acknowledgments}

This work was supported by grant number K12RR023249 and KL2RR024994 from the National Institutes of Health

\section{References}

1. Osler W. Gulstonian lectures on malignant endocarditis. Br Med J 1885;I:467-70. 522-6, 577-9.

2. Bashore TM, Cabell C, Fowler VJ Jr. Update on infective endocarditis. Curr Probl Cardiol 2006;4:274352. [PubMed: 16546554]

3. Tunkel, AR.; Scheld, WM. Experimental models of endocarditis. In: Kaye, D., editor. Infective Endocarditis. New York: Raven Press; 1992. p. 37-61.

4. Wilson W, Taubert KA, Gewitz PB, et al. Prevention of Infective endocarditis: Guidelines form the American Heart Association: A guideline from the American Heart Association Rheumatic Fever, Endocarditis, and Kawasaki Disease Committee, Council on Cardiovascular Disease in the Young, and the Council on Clinical Cardiology, Council on Cardiovascular Surgery and Anesthesia, and the Quality of Care and Outcomes Research Interdisciplinary Working Group. Circulation 2007;116:1736-54. [PubMed: 17446442]

5. Scheld WM, Valvone JA, Sande MA. Bacterial adherence in the pathogenesis of endocarditis. Interaction of bacterial dextran, platelets, and fibrin. J Clin Invest 1978;61:1394-403. [PubMed: 659601]

6. Burnette-Curley D, Wells V, Viscount H, et al. FimA, a major virulence determinant associated with Streptococcus parasanguis endocarditis. Infect Immun 1995;63:4669-74. [PubMed: 7591121]

7. Berlin JA, Abrutyn E, Strom BL, et al. Incidence of infective endocarditis in the Delaware Valley, 1988-1990. Am J Cardiol 1995;76(12):933-6. [PubMed: 7484834]

8. Delahaye F, Goulet V, Lacassin F, et al. Characteristics of infective endocarditis in France 1991: a one year survey. Eur Heart J 1995;16:394-401. [PubMed: 7789383]

9. Moreillon P, Que Y-A. Infective endocarditis. Lancet 2004;363:139-49. [PubMed: 14726169]

10. Cabell CH, Fowler VG Jr, Engemann JJ, et al. Endocarditis in the elderly: Incidence, surgery, and survival in 16,921 patients over 12 years. Circulation 2002;106(19):547.

11. Fowler, VG.; Scheld, WM.; Bayer, AS. Endocarditis and intravascular infections. In: Mandell, GL.; Bennett, JE.; Dolin, R., editors. Mandell, Douglas and Bennett's Principles and Practice of Infectious Diseases. Vol. 6. Philadelphia: Churchill Livingstone; 2005. p. 975-1021.

12. Durack, DT.; Petersdorf, RG. Changes in the epidemiology of endocarditis. In: Kaplan, EL.; Taranta, AV., editors. Infective Endocarditis; An American Heart Association Symposium; Dallas: American Heart Association; 1977. p. 3-23.

13. Griffin MR, Wilson WR, Edwards WD, et al. Infective endocarditis. Olmsted County, Minnesota, 1950 through 1981. JAMA 1985;254:1199-1202. [PubMed: 4021062]

14. Hoen B, Alla F, Selton-Suty C, et al. Changing profile of infective endocarditis: Results of a 1-year survey in France. JAMA 2002;288:75-81. [PubMed: 12090865]

15. Tleyjeh IM, Abdel-Latif A, Rahbi H, et al. A systematic review of population-based studies of infective endocarditis. Chest 2007;132(3):1025-1035. [PubMed: 17873196] 
16. Harris, SL. Definitions and demographic characteristics. In: Kaye, D., editor. Infective Endocarditis. New York: Raven Press; 1992. p. 1-30.

17. Thayer WS. Studies on bacterial (infective) endocarditis. Johns Hopkins Hosp Rep 1926;22:1-8.

18. Miro JM, Anguera I, Cabell CH, et al. Staphylococcus aureus native valve infective endocarditis: Report of 566 episodes from the International Collaboration on Endocarditis Merged Database. Clin Infect Dis 2005;41:507-514. [PubMed: 16028160]

19. Selton-Suty C, Hoen B, Grentzinger A, et al. Clinical and bacteriological characteristics of infective endocarditis in the elderly. Heart 1997;77(3):260-263. [PubMed: 9093046]

20. McDonald JR, Olaison L, Anderson DJ, et al. Enterococcal native valve endocarditis: Report of 107 episodes from the International Collaboration on Endocarditis Merged Database. Am J Med 2005;11:759-66. [PubMed: 15989910]

21. Michel PL, Acar J. Native cardiac disease predisposing to infective endocarditis. Eur Heart J 1995;16 (SupplB):2-9. [PubMed: 7671919]

22. Weinberger I, Rotenberg Z, Zacharovitch D, et al. Native valve infective endocarditis in the 1970s versus 1980s: underlying cardiac lesions and infecting organisms. Clin Cardiol 1990;13:94-8. [PubMed: 2407399]

23. Clemens JD, Horwitz RI, Jaffe CC, et al. A controlled evaluation of the risk of bacterial endocarditis in persons with mitral-valve prolapse. N Engl J Med 1982;307:776-80. [PubMed: 7110242]

24. Gordon SM, Serkey JM, Longworth DL, et al. Early onset prosthetic valve endocarditis: the Cleveland Clinic experience 1992-1997. Ann Thorac Surg 2000;69(5):1388-92. [PubMed: 10881810]

25. Strom BL, Abrutyn E, Berlin JA, et al. Risk factors for infective endocarditis: oral hygiene and nondental exposures. Circulation 2000;102:2842-8. [PubMed: 11104742]

26. Pelletier LL, Petersdorf RG. Infective endocarditis: A review of 125 cases from the University of Washington Hospitals, 1963-72. Medicine (Baltimore) 1977;56:287-99. [PubMed: 875718]

27. Martín-Dávila P, Fortún J, Navas E, et al. Nosocomial endocarditis in a tertiary hospital: An increasing trend in native valve cases. Chest 2005;128:772-9. [PubMed: 16100166]

28. Terpenning MS, Buggy BP, Kaufmann CA. Hospital-acquired infective endocarditis. Arch Intern Med 1988;148:1601-3. [PubMed: 3382305]

29. Mourvillier B, Trouillet JL, Timsit JF, et al. Infective endocarditis in the intensive care unit: clinical spectrum and prognostic factors in 228 consecutive patients. Intensive Care Med 2004;30:2046-52. [PubMed: 15372147]

30. Karth GD, Koreny M, Binder T, et al. Complicated infective endocarditis necessitating ICU admission: clinical course and prognosis. Crit Care 2002;6:149-54. [PubMed: 11983041]

31. Gouello JP, Asfar P, Brenet O, et al. Nosocomial endocarditis in the intensive care unit: an analysis of 22 cases. Crit Care Med 2000;28:377-82. [PubMed: 10708170]

32. Wolff M, Witchitz S, Chastang C, et al. Prosthetic valve endocarditis in the ICU. Prognostic factors of overall survival in a series of 122 cases and consequences for treatment decision. Chest 1995;108:688-94. [PubMed: 7656617]

33. Durack DT, Lukes AS, Bright DK. New criteria for diagnosis of infective endocarditis: utilization of specific echocardiographic findings. Duke Endocarditis Service. Am J Med 1994;96:200-7. [PubMed: 8154507]

34. Bayer AS, Ward JL, Ginzton LE, et al. Evaluation of new clinical criteria for the diagnosis of infective endocarditis. Am J Med 1994;96:211-5. [PubMed: 8154508]

35. Hoen B, Selton-Suty G, Danchin N, et al. Evaluation of the Duke criteria versus the Beth Israel criteria for the diagnosis of infective endocarditis. Clin Infect Dis 1995;21:905-11. [PubMed: 8645838]

36. Li JS, Sexton DJ, Mick N, et al. Proposed modifications to the Duke criteria for the diagnosis of infective endocarditis. Clin Infect Dis 2000;30:633-8. [PubMed: 10770721]

37. Sachdev M, Peterson GE, Jollis JG. Imaging techniques for diagnosis of infective endocarditis. Infect Dis Clin North Am 2002;16:319-37. [PubMed: 12092475]

38. Kuruppu JC, Corretti M, Mackowiak P, et al. Overuse of transthoracic echocardiography in the diagnosis of native valve endocarditis. Arch Intern Med 2002;162:1715-20. [PubMed: 12153374] 
39. Greaves K, Mou D, Patel A, et al. Clinical criteria and the appropriate use of transthoracic echocardiography for the exclusion of infective endocarditis. Heart 2003;89:273-5. [PubMed: 12591829]

40. Baddour LM, Wilson WR, Bayer AS, et al. Infective endocarditis: Diagnosis, antimicrobial therapy, and management of complications. A statement for healthcare professionals from the Committee on Rheumatic Fever, Endocarditis, and Kawasaki Disease, Council of Cardiovascular Disease in the Young, and the Councils on Clinical Cardiology, Stroke, and Cardiovascular Surgery and Anesthesia, American Heart Association. Circulation 2005;6:e394-e434. [PubMed: 15956145]

41. Roe MT, Abramson MA, Li J, et al. Clinical information determines the impact of transesophageal echocardiography on the diagnosis of infective endocarditis by the duke criteria. Am Heart $\mathbf{J}$ 2000;139:945-51. [PubMed: 10827373]

42. Fowler VG, Li J, Corey GR, et al. Role of echocardiography in evaluation of patients with Staphylococcus aureus bacteremia: experience in 103 patients. J Am Coll Cardiol 1997;30:1072-8. [PubMed: 9316542]

43. Feuchtner GM, Stolzmann P, Dichtl W, et al. Multislice computed tomography in infective endocarditis. J Am Coll Cardiol 2009;53:436-44. [PubMed: 19179202]

44. Leibovici L, Vidal L, Paul M. Aminoglycoside drugs in clinical practice: an evidence-based approach. J Antimicrob Chemother 2009;63:246-51. [PubMed: 19022778]

45. Falagas ME, Matthaiou DK, Bliziotis IA. The role of aminoglycosides in combination with a betalactam for the treatment of bacterial endocarditis: a meta-analysis of comparative trials. J Antimicrob Chemother 2006;57:639-47. [PubMed: 16501057]

46. Korzeniowski O, Sande MA. Combination antimicrobial therapy for Staphylococcus aureus endocarditis in patients addicted to parenteral drugs and in nonaddicts: A prospective study. Ann Intern Med 1982;97:496-503. [PubMed: 6751182]

47. Vlessis AA, Hovaguimian H, Jaggers J, et al. Infective endocarditis: Ten-year review of medical and surgical therapy. Ann Thorac Surg 1996;61:1217-22. [PubMed: 8607686]

48. Wang A, Pappas P, Anstrom KJ, et al. The use and effect of surgical therapy for prosthetic valve infective endocarditis: A propensity analysis of a multicenter, international cohort. Am J Heart 2005; 150:1086-91.

49. Tornos P, Iung B, Permanyer-Miralda G, et al. Infective endocarditis in Europe: lessons from the Euro-Heart Survey. Heart 2005;91:571-5. [PubMed: 15831635]

50. Tleyjeh IM, Kashour T, Zimmerman V, et al. The role of valve surgery in infective endocarditis management: A systematic review of observational studies that included propensity score analysis. Am Heart J 2008;156:901-9. [PubMed: 19061705]

51. Vikram HR, Buenconsejo J, Hasbun R, et al. Impact of valve surgery on 6-month mortality in adults with complicated, left-sided native valve endocarditis. JAMA 2003;290:3207-14. [PubMed: 14693873]

52. Cabell CH, Abrutyn E, Fowler VG, et al. Use of surgery in patients with native valve infective endocarditis: Results from the International Collaboration on Endocarditis Merged Database. Am Heart J 2005;150:1092-8. [PubMed: 16291004]

53. Tleyjeh IM, Ghomrawi HM, Steckelberg JM, et al. The impact of valve surgery on 6-month mortality in left-sided infective endocarditis. Circulation 2007;115:1721-8. [PubMed: 17372170]

54. Sexton DJ, Spelman D. Current best practices and guidelines: Assessment and management of complications in infective endocarditis. Cardiol Clin 2003;21:273-82. [PubMed: 12874898]

55. Mylonakis E, Calderwood SB. Infective endocarditis in adults. N Engl J Med 2001;345:1318-30. [PubMed: 11794152]

56. Moon MR, Stinson EB, Miller DC. Surgical treatment of endocarditis. Prog Cardiovasc Surg 1997;40:239-64.

57. Mills J, Utley J, Abbott J. Heart failure in infective endocarditis: Predisposing factors, course, and treatment. Chest 1974;66:151-7. [PubMed: 4852232]

58. Graupner C, Vilacosta I, San Román JA, et al. Periannular extension of infective endocarditis. J Am Coll Cardiol 2002;39:1204-11. [PubMed: 11923047]

59. Akowuah EF, Davies W, Oliver S, et al. Prosthetic valve endocarditis: Early and late outcome following medical or surgical treatment. Heart 2003;89:269-72. [PubMed: 12591827] 
60. Habib G, Tribouilloy C, Thuny F, et al. Prosthetic valve endocarditis: who needs surgery? A multicentre study of 104 cases. Heart 2005;91:954-9. [PubMed: 15958370]

61. Moss R, Munt B. Injection drug use and right sided endocarditis. Heart 2003;89:577-81. [PubMed: 12695478]

62. Miro JM, del Rio A, Mestres CA. Infective endocarditis and cardiac surgery in intravenous drug abusers and HIV-1 infected patients. Cardiol Clin 2003;21:167-84. [PubMed: 12874891]

63. Hoen B, Alla F, Selton-Suty C, et al. Changing profile of infective endocarditis: Results of a 1-year survey in France. JAMA 2002;288:75-81. [PubMed: 12090865]

64. Jain V, Yang M-H, Kovacicova-Lezcano G, et al. Infective endocarditis in an urban medical center: Association of individual drugs with valvular involvement. J Infection 2008;57:132-8.

65. Hecht S, Berger M. Right-sided endocarditis in intravenous drug users. Prognostic features in 102 episodes. Ann Intern Med 1992;117:560-6. [PubMed: 1524330]

66. DiNubile MJ. Short-course antibiotic therapy for right-sided endocarditis caused by Staphylococcus aureus in injection drug users. Ann Intern Med 1994;121:873-6. [PubMed: 7978701]

67. Heldman AW, Hartert TV, Ray SC, et al. Oral antibiotic treatment of right-sided staphylococcal endocarditis in injection drug users: Prospective randomized comparison with parenteral therapy. Am J Med 1996;101:68-76. [PubMed: 8686718]

68. Mahesh B, Angelini G, Caputo M, et al. Prosthetic valve endocarditis. Ann Thorac Surg 2005;80:1151-8. [PubMed: 16122521]

69. Stanbridge TN, Isalska BJ. Aspects of prosthetic valve endocarditis. J Infect 1997;35:1-6. [PubMed: 9279717]

70. Piper C, Körfer R, Horstkotte D. Prosthetic valve endocarditis. Heart 2001;85:590-3. [PubMed: 11303018]

71. Karchmer AW, Longworth DL. Infections of intracardiac devices. Cardiol Clin 2003;21:253-71. [PubMed: 12874897]

72. Baddour, LM.; Wilson, WR. Prosthetic valve endocarditis and cardiovascular device-related infections. In: Mandell, GL.; Bennett, JE.; Dolin, R., editors. Mandell, Douglas and Bennett's Principles and Practice of Infectious Diseases. Vol. 6. Philadelphia: Churchill Livingstone; 2005. p. 1022-44.

73. Habib G, Tribouilloy C, Thuny F, et al. Prosthetic valve endocarditis: who needs surgery? A multicentre study of 104 cases. Heart 2005;91:954-9. [PubMed: 15958370]

74. Sampedro MF, Patel R. Infections associated with long-term prosthetic devices. Infect Dis Clin N Am 2007;21:785-819.

75. Wang A, Athan E, Pappas PA, et al. Contemporary clinical profile and outcome of prosthetic valve endocarditis. JAMA 2007;297:1354-61. [PubMed: 17392239]

76. Cabell C, Heidenreich $\mathrm{P}, \mathrm{Chu} \mathrm{V}$, et al. Increasing rates of cardiac device infections among Medicare beneficiaries: 1990-1999. Am Heart J 2004;147:582-6. [PubMed: 15077071]

77. Arber N, Pras E, Copperman Y, et al. Pacemaker endocarditis: report of 44 cases and review of the literature. Medicine 1994;73:299-305. [PubMed: 7984081]

78. Baddour LM, Bettmann MA, Bolger AF, et al. Nonvalvular cardiovascular device-related infections. Ciculation 2003;108:2015-31.

79. Chua JD, Wilkoff BL, Lee I, et al. Diagnosis and management of infections involving implantable electrophysiologic cardiac devices. Ann Intern Med 2000;133:604-8. [PubMed: 11033588]

80. Tleyjeh IM, Steckelberg JM, Murad HS, et al. Temporal trends in infective endocarditis: a populationbased study in Olmsted County, Minnesota. JAMA 2005;293:3061-2. [PubMed: 15972569]

81. Fowler VG, Miro JM, Hoen B, et al. Staphylococcus aureus endocarditis: A consequence of medical progress. JAMA 2005;293:3012-21. [PubMed: 15972563]

82. Millar BC, Prendergast BD, Moore JE. Community-associated MRSA (CA-MRSA): an emerging pathogen in infective endocarditis. J Antimicrob Chemother 2008;61:1-7. [PubMed: 17962214]

83. Cabell CH, Jollis JG, Peterson GE, et al. Changing patient characteristics and the effect on mortality in endocarditis. Arch Intern Med 2002;162:90-7. [PubMed: 11784225] 
84. Chirouze C, Cabell CH, Fowler VG, et al. Prognostic factors in 61 cases of Staphylococcus aureus prosthetic valve infective endocarditis from the International Collaboration on Endocarditis Merged Database. Clin Infect Dis 2004;38:1323-7. [PubMed: 15127349]

85. Korzeniowski O, Sande MA. Combination antimicrobial therapy for Staphylococcus aureus endocarditis in patients addicted to parenteral drugs and in nonaddicts: A prospective study. Ann Intern Med 1982;97:496-503. [PubMed: 6751182]

86. Leibovici L, Vidal L, Paul M. Aminoglycoside drugs in clinical practice: an evidence-based approach. J Antimicrob Chemother 2008;63:246-51. [PubMed: 19022778]

87. Chu VH, Cabell CH, Abrutyn E, et al. Native valve endocarditis due to coagulase-negative staphylococci: Report of 99 episodes from the International Collaboration on Endocarditis Merged Database. Clin Infect Dis 2004;39:1527-30. [PubMed: 15546091]

88. Anguera I, Del Rio A, Miró JM, et al. Staphylococcus lugdunensis infective endocarditis: description of 10 cases and analysis of native valve, prosthetic valve, and pacemaker lead endocarditis clinical profiles. Heart 2005;91:e10. [PubMed: 15657200]

89. Hoen B, Chirouze C, Cabell CH, et al. Emergence of endocarditis due to group D streptococci: Findings derived from the merged database of the International Collaboration on Endocarditis. Eur J Clin Microbiol Infect Dis 2005;24:12-6. [PubMed: 15660254]

90. Tripodi MF, Adinolfi LE, Ragone E, et al. Streptococcus bovis endocarditis and its association with chronic liver disease: An underestimated risk factor. Clin Infect Dis 2004;38:1394-400. [PubMed: 15156477]

91. Anderson DJ, Olaison L, McDonald JR, et al. Enterococcal prosthetic valve infective endocarditis: Report of 45 episodes from the International Collaboration on Endocarditis Merged Database. Eur J Clin Microbiol Infect Dis 2005;24:665-70. [PubMed: 16244853]

92. Olaison L, Schadewitz K. Enterococcal endocarditis in Sweden, 1995-1999: can shorter therapy with aminoglycosides be used? Clin Infect Dis 2002;34:159-66. [PubMed: 11740702]

93. Gavalda J, Onrubia PL, Gonez MT, et al. Efficacy of ampicillin combined with ceftriaxone and gentamicin in the treatment of experimental endocarditis due to Enterococcus faecalis with no highlevel resistance to aminoglycosides. J Antimicrob Chemother 2003;52:514-7. [PubMed: 12917251]

94. Gavalda J, Len O, Miro JM, et al. Brief Communication: Treatment of Enterococcus faecalis endocarditis with ampicillin plus ceftriaxone. Ann Intern Med 2007;146:574-9. [PubMed: 17438316]

95. Baron EJ, Scott JD, Tompkins LS. Prolonged incubation and extensive subculturing do not increase recovery of clinically significant microorganisms from standard automated blood cultures. Clin Infect Dis 2005;41:1677-80. [PubMed: 16267743]

96. Morpeth S, Murdoch D, Cabell CH, et al. Non-HACEK gram-negative bacillus endocarditis. Ann Intern Med 2007;147:829-35. [PubMed: 18087053]

97. Wieland M, Lederman MM, Kline-King C, et al. Left-sided endocarditis due to Pseudomonas aeruginosa. A report of 10 cases and review of the literature. Medicine (Baltimore) 1986;65:180-9. [PubMed: 3084905]

98. Levine DP, Crane LR, Zervos MJ. Bacteremia in narcotic addicts at the Detroit Medical Center. II Infectious endocarditis: a prospective comparative study. Rev Infect Dis 1986;8:374-96. [PubMed: 3755255]

99. Daniel WG, Mugge A, Martin RP, et al. Improvement in the diagnosis of abscesses associated with endocarditis by transesophageal echocardiography. N Engl J Med 1991;324:795-800. [PubMed: 1997851]

100. Anguera I, Mire JM, Cabell CH, et al. Clinical characteristics and outcome of aortic endocarditis with periannular abscess in the International Collaboration on Endocarditis Merged Database. Am J Cardiol 2005;96:976-81. [PubMed: 16188527]

101. Hill EE, Herijgers $P$, Claus P, et al. Abscess in infective endocarditis: The value of transesophageal echocardiography and outcome: A 5-year study. Am Heart J 2007;154:923-8. [PubMed: 17967599]

102. Mouly S, Ruimy R, Launay O, et al. The changing clinical aspects of infective endocarditis: Descriptive review of 90 episodes in a French teaching hospital and risk factors for death. J Infect 2002;45:246-56. [PubMed: 12423613] 
103. Thuny F, Disalvo G, Belliard O, et al. Risk of embolism and death in infective endocarditis: Prognostic value of echocardiography, a prospective multicenter study. Circulation 2005;112:6975. [PubMed: 15983252]

104. Heiro M, Nikoskelainen J, Engblom E, et al. Neurologic manifestations of infective endocarditis: A 17-year experience in a teaching hospital in Finland. Arch Intern Med 2000;160:2781-7. [PubMed: 11025788]

105. Steckelberg JM, Murphy JG, Ballard D, et al. Emboli in infective endocarditis: The prognostic value of echocardiography. Ann Inter Med 1991;114:635-40.

106. Snygg-Martin U, Gustafsson L, Rosengren L, et al. Cerebrovascular complications in patients with left-sided infective endocarditis are common: A prospective study using magnetic resonance imaging and neurochemical brain damage markers. Clin Infect Dis 2008;47:23-30. [PubMed: 18491965]

107. Dickerman SA, Abrutyn E, Barsic B, et al. The relationship between the initiation of antimicrobial therapy and the incidence of stroke in infective endocarditis: An analysis from the ICE Prospective Cohort Study (ICE-PCS). Am Heart J 2007;154:1086-94. [PubMed: 18035080]

108. Chu VH, Cabell CH, Benjamin DK Jr, et al. Early predictors of in-hospital death in infective endocarditis. Circulation 2004;110:1745-9. [PubMed: 15037538]

109. Wallace SM, Walton BI, Kharbanda RK, et al. Mortality from infective endocarditis: clinical predictors of outcome. Heart 2002;88:53-60. [PubMed: 12067945]

110. Leblebicioglu H, Yilmaz H, Tasova Y, et al. Characteristics and analysis of risk factors for mortality in infective endocarditis. Eur J Epidemiol 2006;21:25-31. [PubMed: 16450203]

111. Hsu CN, Wang JY, Tseng CD, et al. Clinical features and predictors for mortality in patients with infective endocarditis at a university hospital in Taiwan from 1995 to 2003 . Epidemiol Infect 2006;134:589-97. [PubMed: 16238819]

112. Wilson W, Taubert KA, Gewitz M, et al. Prevention of infective endocarditis: Guidelines from the American Heart Association: A Guideline from the American Heart Association Rheumatic Fever, Endocarditis, and Kawasaki Disease Committee, Council on Cardiovascular Disease in the Young, and the Council on Clinical Cardiology, Council on Cardiovascular Surgery and Anesthesia, and the Quality of Care and Outcomes Research Interdisciplinary Working Group. Circulation 2007;116:1736-54. [PubMed: 17446442]

113. Duval X, Alla F, Hoen B, et al. Estimated risk of endocarditis in adults with predisposing cardiac conditions undergoing dental procedures with or without antibiotic prophylaxis. Clin Infect Dis 2006;42:e102-7. [PubMed: 16705565]

114. Agha Z, Lofgren RP, VanRuiswyk JV. Is antibiotic prophylaxis for bacterial endocarditis costeffective? Med Decis Making 2005;25:308-20. [PubMed: 15951458] 
Table 1

Modified Duke Criteria for Diagnosis of Infective Endocarditis

Definite endocarditis requires 2 major criteria, or 1 major and 3 minor criteria, or 5 minor criteria.

Possible endocarditis requires 1 major and 1 minor criterion, or 3 minor criteria.

\begin{tabular}{|c|c|}
\hline Major Criteria: & \\
\hline \multirow[t]{2}{*}{ 1. Microbiologic evidence of IE: } & $\begin{array}{l}\text { Typical organisms cultured from } 2 \text { separate blood cultures: } \\
\text { *Viridans streptococci, Staphylococcus aureus, HACEK organism, or Streptococcus bovis, OR } \\
\text { * Community-acquired enterococcus in the absence of an alternative primary site of infection }\end{array}$ \\
\hline & $\begin{array}{l}\text { Persistently positive blood cultures with other organism: } \\
\text { *At least } 2 \text { positives drawn }>12 \text { hours apart, OR } \\
\text { * All of } 3 \text { or majority of } 4 \text {, with first and last drawn }>1 \text { hour apart } \\
\text { One culture (or phase } 1 \mathrm{IgG}>1: 800 \text { ) for Coxiella burnetii }\end{array}$ \\
\hline $\begin{array}{l}\text { 2. Evidence of enclocarclial } \\
\text { involvement }\end{array}$ & $\begin{array}{l}\text { Echocardiogram showing: } \\
\quad * \text { Oscillating intracardiac mass without alternative explanation, OR } \\
* \text { Abscess, OR } \\
* \text { New partial dehiscence of a prosthetic valve, OR } \\
* \text { New valvular regurgitation }\end{array}$ \\
\hline \multicolumn{2}{|l|}{ Minor Criteria: } \\
\hline $\begin{array}{l}\text { 1. Predisposition to infective } \\
\text { endocarditis: }\end{array}$ & Previous IE, injection drug use, prosthetic heart valve, or cardiac lesion causing turbulent blood flow \\
\hline \multicolumn{2}{|l|}{ 2. Fever $>38 \mathrm{C}$} \\
\hline 3. Vascular phenomenon: & Arterial embolism, pulmonary infarct, mycotic aneurysm, intracranial or conjunctival hemorrhage, or Janeway's lesions \\
\hline 4. Immunologic phenomenon: & Glomerulonephritis, Osler's nodes, Roth's spots, or positive rheumatoid factor \\
\hline $\begin{array}{l}\text { 5. Microbiologic finding not meeting } \\
\text { major criteria }\end{array}$ & \\
\hline
\end{tabular}

Adapted with permission from Li et al. [36] 
Table 2

Selected Native Valve Endocarditis Treatment Regimens All doses based on normal renal function

\begin{tabular}{|c|c|c|c|}
\hline Organism & Drug & Duration & Notes \\
\hline Oxacillin-sensitive Staphylococcus & $\begin{array}{c}\text { oxacillin/nafcillin } 2 \mathrm{~g} \text { IV q4h } \\
\text { WITH OR WITHOUT } \\
\text { gentamicin } 1 \mathrm{mg} / \mathrm{kg} \text { IV/IM q } 8 \mathrm{~h}^{a}\end{array}$ & $\begin{array}{l}6 \text { weeks } \\
3 \text { to } 5 \text { days }\end{array}$ & $\begin{array}{l}\text { For non-anaphylactoid penicillin allergy, } \\
\text { substitute cefazolin } 2 \mathrm{~g} \text { IV } \mathrm{q} 8 \mathrm{~h} \text { for oxacillin/ } \\
\text { nafcillin. For anaphylactoid penicillin } \\
\text { allergy, substitute vancomycin } 15 \mathrm{mg} / \mathrm{kg} \text { IV } \\
\mathrm{q} 12 \mathrm{~h}^{b} \text { for oxacillin/nafcillin, and do not use } \\
\text { gentamicin }\end{array}$ \\
\hline Oxacillin-resistant Staphylococcus & vancomycin $15 \mathrm{mg} / \mathrm{kg}$ IV q12h ${ }^{b}$ & 6 weeks & \\
\hline $\begin{array}{l}\text { Viridans streptococci/S. bovis with penicillin MIC } \\
\leq 0.12 \mu \mathrm{g} / \mathrm{mL}\end{array}$ & $\begin{array}{c}\text { penicillin G } 12-18 \text { million U IV per } 24 \mathrm{~h}^{c} \\
\text { OR } \\
\text { ceftriaxone } 2 \mathrm{~g} \text { IV/IM q24h }\end{array}$ & $\begin{array}{l}4 \text { weeks } \\
4 \text { weeks }\end{array}$ & $\begin{array}{l}\text { For penicillin/ceftriaxone allergy, } \\
\text { vancomycin } 15 \mathrm{mg} / \mathrm{kg} \text { IV q12h }\end{array}$ \\
\hline $\begin{array}{l}\text { Viridans streptococci/S. bovis with penicillin MIC } \\
>0.12 \text { to } \leq 0.5 \mu \mathrm{g} / \mathrm{mL}\end{array}$ & $\begin{array}{c}\text { penicillin G } 24 \text { million U IV per } 24 \mathrm{~h}^{c} \\
\text { PLUS } \\
\text { gentamicin } 3 \mathrm{mg} / \mathrm{kg} \text { IV/IM q24h } \\
\text { OR } \\
\text { ceftriaxone } 2 \mathrm{~g} \text { IV/IM q24h } \\
\text { PLUS } \\
\text { gentamicin } 3 \mathrm{mg} / \mathrm{kg} \text { IV/IM q24h }\end{array}$ & $\begin{array}{l}4 \text { weeks } \\
2 \text { weeks } \\
4 \text { weeks } \\
2 \text { weeks }\end{array}$ & $\begin{array}{l}\text { For penicillin/ceftriaxone allergy, } \\
\text { vancomycin } 15 \mathrm{mg} / \mathrm{kg} \text { IV q } 12 \mathrm{~h}^{b}\end{array}$ \\
\hline $\begin{array}{l}\text { Viridans streptococci/S. bovis or Nutritionally- } \\
\text { variant Streptococci with PCN MIC }>0.5 \mu \mathrm{g} / \mathrm{mL}\end{array}$ & $\begin{array}{l}\text { See treatment regimen for penicillin/ } \\
\text { ampicillin-resistant enterococcal endocarditis }\end{array}$ & - & - \\
\hline $\begin{array}{l}\text { Enterococcus spp. Susceptible to penicillin, } \\
\text { ampicillin, gentamicin, and vancomycin }\end{array}$ & $\begin{array}{c}\text { ampicillin } 2 \mathrm{~g} \mathrm{IV} \mathrm{q4h} \\
\text { PLUS } \\
\text { gentamicin } 1 \mathrm{mg} / \mathrm{kg} \mathrm{IV/IMq} 8 \mathrm{~h}^{a} \\
\text { OR } \\
\text { penicillin G } 18-30 \text { million U IV per } 24 \mathrm{~h}^{c} \\
\text { PLUS } \\
\text { gentamicin } 1 \mathrm{mg} / \mathrm{kg} \mathrm{IV/IMq} 8 \mathrm{~h}^{a}\end{array}$ & $\begin{array}{l}4-6 \text { weeks } \\
4-6 \text { weeks } \\
4-6 \text { weeks } \\
4-6 \text { weeks }\end{array}$ & $\begin{array}{l}\text { For penicillin/ampicillin allergy, } \\
\text { vancomycin } 15 \mathrm{mg} / \mathrm{kg} \mathrm{IV} \mathrm{q} 12 \mathrm{~h}^{b} \text { for } 6 \text { weeks } \\
\text { PLUS gentamicin } 1 \mathrm{mg} / \mathrm{kg} \mathrm{IV} / \mathrm{IM} \mathrm{q} 8 \mathrm{~h}^{a} \text { for } \\
6 \text { weeks }\end{array}$ \\
\hline $\begin{array}{l}\text { Enterococcus spp resistant to penicillin/ampicillin, } \\
\text { susceptible to vancomycin and gentamicin }\end{array}$ & 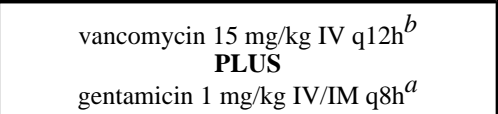 & $\begin{array}{l}6 \text { weeks } \\
6 \text { weeks }\end{array}$ & $\begin{array}{l}\text { If } \beta \text {-lactamase production, ampicillin- } \\
\text { sulbactam } 3 \mathrm{~g} \text { IV q6h PLUS gentamicin } 1 \\
\mathrm{mg} / \mathrm{kg} \text { IV/IM q8hc for } 6 \text { weeks }\end{array}$ \\
\hline
\end{tabular}

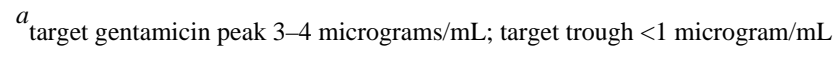

$b_{\text {target vancomycin peak 30-45 micrograms } / \mathrm{mL} \text {; target trough } 10-15 \text { micrograms } / \mathrm{mL}}$

${ }^{c}$ penicillin dosing can be by continuous infusion, or dosed q4-6h in equal divided doses adapted with permission from Baddour LM et al [40]
} 
Table 3

Selected Prosthetic Valve Endocarditis Treatment Regimens All doses based on normal renal function

\begin{tabular}{|c|c|c|c|}
\hline Organism & Drug & Duration & Alternative/Comments \\
\hline Oxacillin-sensitive Staphylococcus & $\begin{array}{l}\text { oxacillin/nafcillin } 2 \mathrm{~g} \mathrm{IV} \mathrm{q} 4 \mathrm{~h} \\
\text { PLUS } \\
\text { rifampin } 300 \mathrm{mg} \text { IV/PO q } 8 \mathrm{~h} \\
\text { PLUS } \\
\text { gentamicin } 1 \mathrm{mg} / \mathrm{kg} \mathrm{IV/IM} \mathrm{q8h}{ }^{a}\end{array}$ & $\begin{array}{l}\geq 6 \text { weeks } \\
\geq 6 \text { weeks } \\
2 \text { weeks }\end{array}$ & 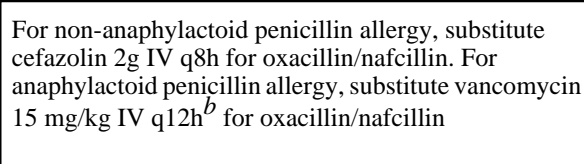 \\
\hline Oxacillin-resistant Staphylococcus & $\begin{array}{c}\text { vancomycin } 15 \mathrm{mg} / \mathrm{kg} \mathrm{IV} \mathrm{q12h} \mathrm{h}^{b} \\
\text { PLUS } \\
\text { rifampin } 300 \mathrm{mg} \text { IV/PO q8h } \\
\text { PLUS } \\
\text { gentamicin } 1 \mathrm{mg} / \mathrm{kg} \text { IV/IM q8h }{ }^{a}\end{array}$ & $\begin{array}{l}\geq 6 \text { weeks } \\
\geq 6 \text { weeks } \\
2 \text { weeks }\end{array}$ & \\
\hline $\begin{array}{l}\text { Viridans streptococci/S. bovis } \text { with penicillin } \\
\text { MIC } \leq 0.12 \mu \mathrm{g} / \mathrm{mL}\end{array}$ & $\begin{array}{c}\text { penicillin G } 24 \text { million U IV per } 24 \mathrm{~h}^{c} \\
\text { WITH OR WITHOUT } \\
\text { gentamicin } 3 \mathrm{mg} / \mathrm{kg} \text { IV/IM q24h } \\
\text { OR } \\
\text { ceftriaxone } 2 \mathrm{~g} \text { IV/IM q24h } \\
\text { WITH OR WITHOUT } \\
\text { gentamicin } 3 \mathrm{mg} / \mathrm{kg} \text { IV/IM q24h }\end{array}$ & $\begin{array}{l}6 \text { weeks } \\
2 \text { weeks } \\
6 \text { weeks } \\
2 \text { weeks }\end{array}$ & $\begin{array}{l}\text { For penicillin/ceftriaxone allergy, vancomycin } 15 \mathrm{mg} / \\
\mathrm{kg} \mathrm{q} 12 \mathrm{~h}^{b} \text { for } 6 \text { weeks without gentamicin }\end{array}$ \\
\hline $\begin{array}{l}\text { Viridans streptococci/S. bovis with penicillin } \\
\text { MIC }>0.12\end{array}$ & $\begin{array}{c}\text { penicillin G } 24 \text { million U IV per } 24 \mathrm{~h}^{c} \\
\text { PLUS } \\
\text { gentamicin } 3 \mathrm{mg} / \mathrm{kg} \mathrm{IV} / \mathrm{IM} \mathrm{q} 24 \mathrm{~h} \\
\text { OR } \\
\text { ceftriaxone } 2 \mathrm{~g} \text { IV/IM q24h } \\
\text { PLUS } \\
\text { gentamicin } 3 \mathrm{mg} / \mathrm{kg} \mathrm{IV/IM} \mathrm{q24h}\end{array}$ & $\begin{array}{l}6 \text { weeks } \\
6 \text { weeks } \\
6 \text { weeks } \\
6 \text { weeks }\end{array}$ & $\begin{array}{l}\text { For penicillin/ceftriaxone allergy, vancomycin } 15 \mathrm{mg} / \\
\mathrm{kg} \mathrm{q} 12 \mathrm{~h}^{b} \text { for } 6 \text { weeks without gentamicin }\end{array}$ \\
\hline Enterococcus spp. & $\begin{array}{l}\text { PVE treatment regimens identical to } \\
\text { NVE treatment regimens. See Table } 2 \text {. }\end{array}$ & - & - \\
\hline
\end{tabular}

